\title{
PROJECT DELIVERY CONTRACT LANGUAGE, SCHEDULES, AND COLLABORATION
}

\author{
Thais da C. L. Alves ${ }^{1}$, Manuel Martinez ${ }^{2}$, Min Liu ${ }^{3}$, and Natalie M. Scala ${ }^{4}$
}

\begin{abstract}
The construction industry has developed a variety of project delivery methods, contractual arrangements, and scheduling methods in order to facilitate collaboration of stakeholders to maximize project performance. It is critical to investigate how project delivery methods and contractual arrangements might influence collaboration during scheduling practice. Understanding this influence can help managers choose/adapt available project delivery methods to their needs and develop strategies to enforce collaboration when they plan for future projects. This research reviewed contractual language in project delivery methods from the perspective of how those methods accommodate stakeholders' collaboration. Twenty-six professionals were also interviewed to reveal their insights on how contractual arrangements influence collaborative scheduling practices. Contract clauses were identified and categorized based on their level of supporting compliance or collaboration. Finally, the results from the interviews were compared and contrasted with the analysis of contracts for cross validation. Results show that schedules are commonly used as contractual documents, and a need exists to improve contractual arrangements to address the lack of application of collective knowledge to develop, review, and validate schedules for construction projects regardless of the delivery method used.
\end{abstract}

\section{KEYWORDS}

Collaboration, transactional, relational, language, schedules.

\section{INTRODUCTION}

Delivery methods, or delivery systems, are forms of organizing different parties and their contractual relationships in order to deliver construction projects. Historically, the delivery of projects was concentrated in the hands of a single entity who worked as the master builder and was in charge of multiple aspects of the project, including but not limited to, design, construction, logistics, scheduling, contracting labor, and identifying the need for specialized trades. This original form of organizing to build projects

Associate Professor, Civ., Const. \& Env. Eng. Dept., San Diego State University, San Diego, CA, 92182, USA, +1 619 594-8289, talves@ @dsu.edu, orcid.org/0000-0001-7928-9190

2 Research Assistant, Civ., Const. \& Env. Eng. Dept., San Diego State University, San Diego, CA, 92182,USA, manamrt1@ gmail.com, orcid.org/0000-0001-6093-6212

3 Associate Professor, Civ., Const. \& Env. Eng. Dept., North Carolina State Univ., Raleigh, NC 27695, USA, +1 919 513-7920, mliu2@ @ ncsu.edu, orcid.org/0000-0002-3070-7109

4 Associate Professor and Graduate Program Director, Towson Univ., Towson, MD 21252, USA, +1 410 704-2773, nscala@ towson.edu, orcid.org/0000-0003-2851-134X 
constructed the Egyptian pyramids, the European cathedrals, and the infrastructure and roads that linked the Roman Empire and Inca civilization.

However, as trades developed and formed guilds and professions became more specialized from design to construction, the need to organize the work of multiple trades became a profession of its own and required more time spent on construction management. The role of the master builder was split into at least that of a designer, a builder, and a manager; after the Industrial Revolution started in the $18^{\text {th }}$ century and accelerated over the 19th century, the role of trades unfortunately started being viewed as expendable, having less and less to do with the overall planning of construction project activities and more focus on putting work in place (Mulligan and Knutson 2000).

In this environment, the traditional delivery method of having separate entities in charge of different tasks and parts of the project emerged, giving way to the Design-BidBuild (DBB) delivery method, to which other methods are compared against (Sweet et al. 2015). The form is used by different delivery methods to organize project stakeholders, define their rights and responsibilities, impact how parties work together, and determine whether they are more or less collaborative, ultimately impacting project performance (El Asmar et al. 2013). Previous research has shown that the language in contracts tends to be more prescriptive, transactional, and devoid of words that allude to collaboration and related practices in more traditional delivery methods that use dyadic contracts, whereas the language is more relational and collaborative in delivery methods with multi-party contracts (Willis and Alves 2019).

This study builds on previous research about contract language and centers its investigation on the development and implementation of schedules. The research objective is to study how the language in different project delivery methods and contractual arrangements influence scheduling practice and collaboration among stakeholders. The authors documented reports from practice, collected via interviews, and contractual language for different delivery methods, using a review of available contracts. The working hypothesis of this study is that more traditional delivery methods based on dyadic contractual relationships in general provide few to no opportunities or incentives for people to collaborate, whereas more collaborative and multi-party contracts have more specific language calling for the development of collaborative schedules. This paper is structured with a literature review that informed the research and discussion of results, followed by the research method, the analysis of results, and conclusions.

\section{DELIVERY METHODS, SCHEDULE PRACTICES, AND HOW THEY ADDRESS COLLABORATION}

This section presents an overview of delivery methods as they relate to this study, focusing both on the methods used in contract analysis that were also discussed by interviewees and on common schedule practices.

\section{DELIVERY METHODS}

The focus of this study centers on the first four delivery methods described below and three more that were mentioned during the interviews. A brief description of each is provided to support the discussion presented (Sweet et al. 2015).

Design-Bid-Build (DBB) represents the traditional delivery method where an owner initially hires a designer to design the project, later putting the project out for bid once it is designed, and finally hiring the contractor who usually offers the lowest price to build the project. While in $\mathrm{DBB}$, the design continues to be developed via submittals after its 
award (Pestana et al. 2012). Designers and builders do not work together and are separated by the existence of separate contracts with the owner or between the general contractor and the specialized trades, who are hired sequentially and have no input on the design and little, if no, input on the project schedule.

Construction Management at Risk (CMAR) is used when the owner retains the services of the general contractor as a construction manager (CMgr) to manage the project starting from the design stage and provide advice during the preconstruction phase. Later, the CMgr hires additional trades to build the job as needed. The CMgr and the designer might work with additional trades providing support via design-assist contracts, as described below, and start collaborating on schedule development.

Design-Build (DB) consists of a more collaborative delivery method; the DB, and more recently the progressive DB, brings the architect and the general contractor together on a single contract at the start, when they are awarded the project as a team. In some cases, the DB team might choose to have trade partners working with them from the inception of the project; this will depend on how the request for proposals is structured by the owner. This will set the tone in terms of how much collaboration will happen between the parties involved from the start of the project. Moreover, DB contracts usually spell out specific methods to support schedule collaboration (Willis and Alves 2019).

Integrated Project Delivery (IPD) is the more recent of the delivery methods discussed here. IPD projects rely on multi-party contracts where the owner and the parties involved are signatories of a single contract and share risks and rewards. The agreement spells out commercial and organizational terms, which are present in contracts for other delivery methods, as well as the operating terms. The operating terms in IPD contracts are based on Lean Construction methods, tools, and tenets as espoused in the IGLC and professional literature promoted by industry organizations (Darrington et al. 2009, LCI 2021). Thus, schedule collaboration is present from the project's inception.

Construction Management (CM) is commonly employed in an environment where the owner holds multiple prime contracts and hires a construction manager to oversee activities. The CMgr in this case represents the owner but is not at risk for the project's performance.

Engineer-Procure-Construct (EPC) are often used in the oil and gas, chemical, and petrochemical industries and somewhat resemble the organization of the DB method. This might be because a single entity, with a diverse skillset to perform multiple tasks, is in charge of engineering the project, procuring its components, and building it or building via alliances between different companies like in DB.

Design-Assist (DA) involves specialized organizations providing expertise on an asneeded basis as the design is developed. Designers and contractors hired on a DA-basis might not be part of the team that will ultimately build the project. They provide solutions that might end up being built by others.

While other delivery methods and variations of the ones presented herein are available, the scope of this study is limited to these methods which are prevalent in the construction industry in the United States where the study was developed.

\section{Schedule Practices}

Considering the delivery methods discussed and how their organization and related contractual relationships impact collaboration, the way schedules and their development are treated varies across the methods reviewed. 
Given the prevalence of DBB in construction in the United States and around the world, methods and tools that support the mechanisms outlined in DBB contracts have been at the forefront of construction engineering management (CEM) research for 70+ years, with the critical path method (CPM) extensively required in contracts as the method of choice to generate schedules, dominating this body of knowledge and practice (Olivieri et al. 2019). Exceptions considering the use of line of balance to schedule projects like the Empire State Building (Willis and Friedman 1998) as well as other efforts to bring it to the forefront of scheduling construction projects in the mid- to late $20^{\text {th }}$ century are also found. The longstanding CEM literature on schedule development and management is packed with the development of algorithms to support generation of schedules, the use of schedules to address claims, and the definition of metrics to manage schedules (e.g., earned value method).

The IGLC community started offering alternatives to the use of CPM schedules to manage construction projects starting from the early 1990s, based on the seminal work of Glenn Ballard and Greg Howell with the Last Planner System (LPS) (Howell and Ballard 1994, Ballard 2000), and later of others building on LPS-related work (Gonzalez et al. 2009; Viana et al. 2011; Hamzeh et al. 2015), line of balance (Kemmer et al. 2008), and takt planning (Frandson et al. 2013), to name a few. The line of work adopted by the IGLC community is very much centered on the idea promoted by the LPS that construction projects are socio-technical systems and need to be treated as such where the social part, involving interactions between project participants and their engagement, is as important as the technical solutions they are developing (Ballard and Tommelein 2016).

\section{RESEARCH METHOD}

This section describes how the study unfolded, including the details of the interview process and the analysis of contracts.

\section{INTERVIEWS}

Interviews of one or two industry practitioners at a time were usually conducted using Zoom or WebEx, with a few face-to-face ones, by researchers who documented statements provided by the interviewees. Three principal investigators were involved in the study, along with two graduate students. One of the researchers participated in all interviews, and at least two of these five researchers were present on any interview call. The transcripts would later be provided to the interviewees for review and validationas well as to allow them to provide additional comments if they had any. Out of a longer list of questions included in the interview, the following two are discussed in this paper: (1) What type of contract/delivery method was used between different stakeholders - owner, contractors, managers, subcontractors? (e.g., design-build, design-bid-build, construction manager at risk); and (2) Can you indicate any contractual arrangements and/or requirements that might influence how planning for this project is carried out? (e.g., LEED certification of the project, use of pull planning sessions, use of target value design during the design phase, and specific cost targets shared during construction.). Interviews were conducted from August 2019 through February 2020. In total, 26 professionals were interviewed in 24 interviews. Interviewees had a combined 604 years of experience, with a minimum of 5 years and a maximum of 50 years, and included owners (11), contractors (7), consultants (6), specialty contractor (1), and supplier (1). The interviews, which also included additional questions about schedule collaboration, lasted from 30 to 70 minutes. 


\section{CONTRACT ANALYSIS}

The authors' interest in reviewing contracts to explain how schedules are addressed and developed in different delivery methods started with a comment by a practitioner regarding some contractual rules regarding schedules which stifle collaboration: some owners give contractors two weeks to provide and commit to a full schedule once the award is made and that leaves little time for them to collaboratively develop schedules when trade partners are not yet on board. With that in mind, the authors analyzed a group of contracts, previously collected by the first author and her students, and singled out the schedule-related clauses.

Once the clauses were identified, they were categorized as schedule-related clauses supporting one of the three purposes: compliance either in terms of (1) supporting owner requirements, (2) supporting government requirements, or (3) supporting collaboration. Clauses that supported compliance were further categorized as contractual responsibilities and obligations related to providing a schedule for the purposes of time and progress (master schedule), payment (schedule of values), submittals (design), services (consultant's work), materials and equipment (procurement), and dispute resolution processes. The analysis is grounded on a collaborative scheduling maturity model (CII 2021) which, amongst other areas, considers three levels of maturity when addressing the development and implementation of collaborative schedules. An excerpt of the model is shown in Table 1.

Table 1: Maturity Levels and Questions Considered During the Analysis (CII 2021)

\begin{tabular}{|c|c|c|c|}
\hline \multirow[t]{2}{*}{ Question } & \multicolumn{3}{|c|}{ Maturity Level } \\
\hline & Bronze & Silver & Gold \\
\hline $\begin{array}{l}\text { Schedule } \\
\text { created } \\
\text { primarily... }\end{array}$ & $\begin{array}{l}\text { To define contractual } \\
\text { expectations \& } \\
\text { responsibilities but not used. }\end{array}$ & $\begin{array}{l}\text { To define contractual } \\
\text { expectations \& } \\
\text { responsibilities but was not } \\
\text { used by entire project } \\
\text { team. }\end{array}$ & $\begin{array}{c}\text { To enable strong project } \\
\text { management communication and } \\
\text { collaboration throughout project } \\
\text { team. }\end{array}$ \\
\hline Stakeholders & $\begin{array}{l}\text { Were not involved early } \\
\text { enough or considered in } \\
\text { schedule creation. }\end{array}$ & $\begin{array}{c}\text { Were involved early } \\
\text { enough but not all } \\
\text { appropriate and necessary. }\end{array}$ & $\begin{array}{l}\text { Were appropriate and involved } \\
\text { early enough in creating the } \\
\text { schedule. }\end{array}$ \\
\hline There were... & $\begin{array}{l}\text { Little to no use of scheduling } \\
\text { tools and methods utilized } \\
\text { company wide (beyond } \\
\text { scheduling software, ex. } \\
\text { P6). }\end{array}$ & $\begin{array}{l}\text { Use of additional } \\
\text { tools/methods to support } \\
\text { collaboration during } \\
\text { schedule development. }\end{array}$ & $\begin{array}{c}\text { Frequent updates of the schedule } \\
\text { across the project; living, } \\
\text { integrated document with } \\
\text { appropriate tools and methods } \\
\text { used (ex. LPS, BIM, 4D, AWP } \\
\text { Takt Planning). }\end{array}$ \\
\hline
\end{tabular}

A total of $10 \mathrm{DBB}, 9 \mathrm{CM} / \mathrm{CMAR}, 9 \mathrm{DB}$, and $10 \mathrm{IPD}$ contracts (agreements) and related documents (e.g., general conditions, appendixes) were analyzed. The root "schedul" was searched in all contracts, and results were organized in Excel spreadsheets. The hypothesis defined for this part of the study was that schedules and the scheduling task are treated in static and prescriptive ways by less collaborative delivery methods and in more dynamic ways by collaborative delivery methods.

\section{RESULTS}

This section presents the results obtained from the interviews and contract analysis, previously described, and concludes with a cross-analysis of the two approaches used. 


\section{INTERVIEWS}

Table 2 indicates the different delivery methods employed in the projects which were used by the interviewees for the interviews; the absense of IPD projects is noted. It should be noted that the first line lists the most common mentions made by interviewees, whereas the other lines include additional comments made about the various forms in which the projects they worked on were delivered. The third comment is insightful as the interviewee points to the importance of working to impart changes on alternative delivery methods that are more prevalent as a means to change the industry. As shown in Table 2, owners adopt different arrangements to procure and award contracts and that impacts how teams are assembled and work together. Delivery methods are also less defined than usually documented in the literature and adapted to cater to the needs of different projects and owner organizations.

Table 2: Delivery Methods, Contract Types, and Some Variations Used for the Projects Discussed During the Interviews

Delivery Methods (As Reported)
Design-Bid-Build, Design-Build, Construction Management at Risk, "pure" Construction Management Design-Assist,
Engineering-Procure-Construct.
Engineering and construction firms invoice the owner for the work completed. Invoicing based on hourly rate+profit.
Cost plus work is defined in work packages and then build.
Most are Design Build and CM at risk. DB is responsible for a little less than $40 \%$ in a dollar basis of all non-
residential construction in the United States, and CM at risk is around that too. Try not to focus on IPD only to get
the desired collaborative behaviors because that's not where the change will occur most quickly.
$\begin{array}{r}\text { Oil and gas, LNG plants, and offshore platforms - Lump Sum. Now it is more global projects, including chemical } \\ \text { plants, refineries, and long pipelines; cost reimbursable projects. In reality the owner works mostly with EPC, } \\ \text { sometimes EP and the C separate, and the owner does some procurement for long lead items. In a few cases they } \\ \text { do engineering internally. } \\ \text { EP-C. They have an engineering and procurement contractor and a separate reimbursable contract for the } \\ \text { contractor. }\end{array}$
$\begin{array}{r}\text { The owner acts as program manager and contracts out to contractors directly. Also has } 18 \text { internal crews. Contract } \\ \text { out installation. The owner holds four design contracts with four firms. Use blanket contracts valid for } 3 \text { years and bid } \\ \text { every three years. Scorecard used to weight items related to quality, safety record, cost, previous projects, and use } \\ \text { best value. }\end{array}$
Alliance engineers and alliance contractors. The engineers had one contract, and the builders had a separate
contract.

Considering the diverse types of methods used by the interviewees to deliver projects, Table 3 summarizes some of the answers given in terms of any contractual arrangements that might have influenced how they planned the project and developed their schedules, linking them to the levels outlined in Table 1 (maturity model excerpt). Interviewees' comments were edited to shorten long passages as they described arrangements but reflect their experiences and perceptions regarding the topic of collaborative schedules. Not all interviewees answered this question in its entirety, and some did not know the details of the contracts in place. Some noteworthy comments address the fact that people do not know how to work collaboratively to develop schedules, owners do not care about how the project will get built, use of schedules with differing levels of enforcement depending on the contract payment type (i.e., lump sum/fixed price, reimbursable), and vague or completely absent languange regarding schedules and milestones. On the bright side, some interviewees pointed to specific language being added to their contracts requiring the development of collaborative schedules. 
Table 3: Examples of Contractual Arrangements Described in the Interviews

\begin{tabular}{|c|c|}
\hline $\begin{array}{l}\text { Purpose } \\
\text { /Maturity } \\
\text { Level }\end{array}$ & $\begin{array}{c}\text { Example } \\
\text { (related delivery method(s) used as reference by interviewees indicated in } \\
\text { parenthesis) }\end{array}$ \\
\hline $\begin{array}{l}\text { Collaboration } \\
\text { /Gold }\end{array}$ & $\begin{array}{l}\text { The contract delivery is design-build which requires a certain level of collaboration. They have } \\
\text { pull-planner/LPS verbiage which is something that he introduced in the contracts they have in } \\
\text { <location>. Generically, contract says something like: the team members have to allocate two } \\
\text { hours per week for pull planning. Even so, the foremen's meeting is centered around planning } \\
\text { and identifying road-blocks. During the meetings they look at the plan "did you make it or not"? } \\
\text { The scheduler or whoever is taking notes then captures the reasons for non-completion and } \\
\text { adds to a report. (Design-Build) }\end{array}$ \\
\hline $\begin{array}{l}\text { Owner } \\
\text { Requirements } \\
\text { /Gold }\end{array}$ & $\begin{array}{l}\text { They have some standard legal language added to the subcontractors' documents to follow how } \\
\text { they plan. Sometimes they indicate the software and equipment requirements (e.g. iPads) to } \\
\text { make things work. (Design-build with some variations; DB for the most part, mostly variations } \\
\text { with collaborative contracts like IPDs) }\end{array}$ \\
\hline $\begin{array}{l}\text { Collaboration } \\
\text { /Silver }\end{array}$ & $\begin{array}{l}40-50 \% \text { of the projects have some kind of language requiring LPS practices in the contract, } \\
\text { some very minor language. Two of their clients are including wording in contracts in terms of } \\
\text { just-in-time deliveries, participation of foremen in weekly work plans, and the number of hours } \\
\text { required for participation. Some contracts require that specific people participate in the weekly } \\
\text { work plan. (Primarily CM at Risk and pure CM) }\end{array}$ \\
\hline $\begin{array}{l}\text { Collaboration } \\
\quad \text { /Silver }\end{array}$ & $\begin{array}{c}\text { There is an addendum in the trade partners' contracts with the GC which requires the trade } \\
\text { partners to participate in and support collaborative planning meetings at medium- and short-term } \\
\text { levels. Not at the long term, because these are not IPD projects. Trade partners were } \\
\text { complaining of having to do too much work by attending these meetings; now this is required in } \\
\text { contracts. (For the most part CM at Risk) }\end{array}$ \\
\hline $\begin{array}{l}\text { Owner } \\
\text { Requirements } \\
\text { /Silver }\end{array}$ & $\begin{array}{l}\text { Advanced work packaging was mandated. Prioritize certain systems in certain dates, and the } \\
\text { owner was pretty harsh if these were not met. (EPC) }\end{array}$ \\
\hline $\begin{array}{l}\text { Owner } \\
\text { Requirements } \\
\text { /Bronze }\end{array}$ & $\begin{array}{l}\text { Surprising how few projects put anything in contracts regarding collaborative schedules and how } \\
\text { few projects talk about collaborative scheduling formally in the project. Lots of teams doing } \\
\text { progressive design build, but out of } 10 \text { teams they had one team doing it right for collaboration } \\
\text { and 2-3 were nibbling on it. People don't know how to work differently, collaboratively. (Primarily } \\
\text { design-build, but also DBB, and CM at Risk) }\end{array}$ \\
\hline $\begin{array}{l}\text { Owner } \\
\text { Requirements } \\
\text { /Bronze }\end{array}$ & $\begin{array}{l}\text { For any owner that requires a detailed CPM schedule in the beginning of the project, } 30,000- \\
40,000 \text { activities very detailed with attached dates that will not materialize. Why plan with that } \\
\text { level of detail? It is insane. If it is a DB team and they don't have all trades engaged, they can } \\
\text { put the overall sequence of work together but not get into too much detail. Have a CM and an } \\
\text { architect in the room to establish an environment of collaboration. (Most are Design Build and } \\
\text { CM at risk) }\end{array}$ \\
\hline $\begin{array}{l}\text { Owner } \\
\text { Requirements } \\
\text { /Bronze }\end{array}$ & $\begin{array}{l}\text { A lot of projects require the } \mathrm{P} 6 \text { schedule, and they want a contractual schedule. The owner } \\
\text { doesn't really care how you'll get it done and let you think about the means and methods. } \\
\text { (Design-Build) }\end{array}$ \\
\hline $\begin{array}{l}\text { Owner } \\
\text { Requirements } \\
\text { /Silver }\end{array}$ & $\begin{array}{l}\text { In the past, they had some schedule language that was vague and didn't mean much. The } \\
\text { owner could not hold anyone accountable, and they have reviewed it. They focused on refining } \\
\text { planning and scheduling language in contracts to outline need for hours and estimates, really } \\
\text { making sure contractors are holding to change order process that can get earned value } \\
\text { information needed on weekly basis. [...] The contractors know they have a level of expectation } \\
\text { from the schedule department, and in the documentations, they state the expectations that the } \\
\text { contractor has to participate. In the letter of intent or bridge funding, the needs are outlined in } \\
\text { these documents. (EPC) }\end{array}$ \\
\hline $\begin{array}{l}\text { Owner } \\
\text { Requirements } \\
\text { /Bronze }\end{array}$ & $\begin{array}{l}\text { Weaker area, they do not really build schedules or put milestones in their purchase orders. } \\
\text { There are planned execution levels, and contractors are penalized if they are not completing } \\
\text { activities per plans. Contractors are required to develop and provide the schedule weekly. No } \\
\text { milestones are put in the contracts; the only lever is that they baseline an expected execution } \\
\text { index, i.e., number of activities completed divided by number of activities planned. (CM Multi- } \\
\text { prime - Owner as primary manager) }\end{array}$ \\
\hline $\begin{array}{l}\text { Owner } \\
\text { Requirements } \\
\text { /Bronze }\end{array}$ & $\begin{array}{l}\text { Did not have anything in the contract; there was an incentive-based contract based on cost. In } \\
\text { this case, there was already confidence that the GC would give the best schedule. (Design- } \\
\text { Build) }\end{array}$ \\
\hline
\end{tabular}




\section{CONTRACT ANALYSIS}

The clauses investigated mostly fell onto the lowest tier (bronze) of the maturity model displayed in Table 1, with a focus on compliance, and little to no mention of collaborative efforts or additional tools and methods to support the scheduling effort. These clauses were found in all analyzed delivery methods, as all contracts have commercial terms which use the schedule as a reference for multiple types of responsibilities and obligations, indicated in the categorization previously mentioned. Examples of content in such clauses include:

- The contractor shall prepare/present/review the <progress, payment, submittal, inspection, etc.> schedule to the owner.

- The contractor/architect shall review <progress, payment, submittal, inspection, etc.> schedule for compliance/conformance.

- Mentions of the schedule milestones and phases plus related obligations about the development of work, payments, inspections, and/or excused/inexcusable days.

Clauses that supported collaboration could have fallen in any of the previous designations for compliance, but they had one main difference: the clauses clearly called for collaboration with other project participants to provide input to develop schedules beyond simply complying with the requirement of turning in documents as a requirement or an obligation. The clauses would fall towards the Silver and Gold categories of the maturity model presented in Table 1. The schedule would be developed in a more participatory environment including at a minimum the owner, the architect, and the general contractor, with different tools and methods to support its development in a more dynamic type of environment. In this case, the schedule is not recognized solely as a compliance document (static); instead it evolves as participants join the project and give input to its constant development (dynamic). Some examples that illustrate these clauses include mentions to:

- Parties shall jointly develop the schedule, the target cost, project goals, and definitions.

- The core group shall engage in <specific tasks> and meet regularly.

- The team shall employ pull planning to develop the schedule, collaboratively developing weekly work plans that are used to track progress.

- Constructability and work structuring are part of the process of collaboratively designing the project and planning its execution (which impacts work packages and the flow of activities in the schedules).

- Activities and processes from multiple stakeholders are included in the schedule and submitted for review, validation, and approval by the core group.

The contracts for DB and IPD projects displayed a higher frequency of clauses that called for collaborative schedule development, whereas these clauses were virtually absent in the DBB contracts and somewhat present in the CM/CMAR contracts. DB and IPD contracts are also specific in terms of what additional methods and tools are to be used to promote schedule collaboration.

\section{Cross-Analysis AND DiscuSSION}

Results from the interviews (Table 3), when compared and contrasted with the analysis of contracts, offer some insights in terms of the relationship between delivery methods, schedule development, and collaboration. The analysis of contracts offers support to the hypothesis that schedules and the scheduling task are treated in somewhat static and prescriptive ways by less collaborative delivery methods and in more dynamic ways by 
collaborative delivery methods, as defined by the maturity model excerpt shared in Table 1. However, when the interview results are considered, interviewees shared a wide range of possibilities (categorized in different maturity levels) related to schedule development, regardless of the delivery methods used as reference for the interviews. Moreover, some interviewees indicated awareness of contractual clauses and how they support the development of collaborative schedules, whereas others pointed out to additional work to be done in this area. Some contracts, as reported, appeared to be entirely silent about schedule collaboration.

In general terms, based on the contract analysis, schedules are still very much viewed as documents that need to be produced and submitted to the owner in order to address compliance to the contract and serve as a baseline for progress and payment monitoring. Additionally, opportunities are missed when contracts are mostly focused on project management and do not explicitly call for the use of collaborative practices to develop and execute schedules in practice to also support production management (Olivieri et al. 2019). The lack of use of the collective knowledge and experience of teams to develop, review, and validate schedules is lost and remains an area that needs to be addressed in modern construction projects.

\section{CONCLUSIONS}

This study interviewed practitioners and reviewed contracts associated with project delivery methods to understand how the language associated with these methods might help to facilitate schedule collaboration among stakeholders. Interviewees indicated a broad range of ways (categorized in different maturity levels) in which contracts for different delivery methods address or are silent in terms of how to promote collaboration as schedules are developed. Within this group, there was no clear indication that, for instance, DB projects had more specific language about schedule collaboration. Conversely, the contract analysis revealed that DB and IPD projects did in fact display a higher frequency of clauses that called for collaborative schedule development, whereas these clauses were virtually absent in the DBB contracts and somewhat present in the $\mathrm{CM} / \mathrm{CMAR}$ contracts. This contrast between what was observed during the interviews and the contract analysis might indicate that participants have the freedom to decide how to develop and implement their schedules on a more ad-hoc fashion, which might or might not lead to collaborative work. The authors are not advocating for any specific language related to schedule collaboration to be added to the contracts. However, leaving this area silent, or not providing grounds to encourage collaboration, might continue to contribute to the use of schedules as compliance documents with their development by isolated professionals without the support of the collective knowledge available in projects.

\section{ACKNOWLEDGMENTS}

The authors would like to thank the anonymous practitioners who participated in the interview process, the Construction Industry Institute (CII) for project funding, and Dominique Hawkins and Vincent Schiavone for support during the interviews. The results and analyses presented reflect the work of the authors and not of the funding organization.

\section{REFERENCES}

Ballard, H.G. (2000). The last planner system of production control. Thesis (Doctor of Philosophy), School of Civil Engineering, University of Birmingham. 
Ballard, G. and Tommelein, I. (2016). Current Process Benchmark for the Last Planner System. Project Production Systems Laboratory (P2SL), University of California Berkeley, CA. Available at p2sl.berkeley.edu.

Construction Industry Institute [CII] (2021). Breaking through to Collaborative Scheduling: Approaches and Obstacles. Final Report 362. The University of Texas at Austin, Texas. 135pp.

Darrington, J., Dunne, D., and Lichtig, W. (2009). "Organization, Operating System, and Commercial Terms." Managing Integrated Project Delivery. CMAA, McLean, Virginia, 10-47.

El Asmar, M., Hanna, A.S., and Loh, W. (2013). "Quantifying Performance for the Integrated Project Delivery System as compared to Established Delivery Systems." J. Constr. Eng. Manage., ASCE. 139(11): 04013012.

Frandson, A., Berghede, K., and Tommelein, I.D., (2013). Takt time planning for construction of exterior cladding. Proc. 21th Annual Conference of the International Group for Lean Construction. Fortaleza, Brazil. pp. 527-536.

Gonzalez, V., Alarcon, L. F. , Maturana, S. , Mundaca, F., and Bustamante, J. A. (2009). "Rational Commitment Model: Improving Planning Reliability and Project Performance." Proc. 17th Annual Conference of the International Group for Lean Construction.Taipei, Taiwan, pp 207-218.

Hamzeh, F., Kankoul, E., and Rouhana, C. (2015). "How can 'tasks made ready' during lookahead planning impact reliable workflow and project duration?" Construction Management and Economics, 33 (4), 243-258.

Howell, G. and Ballard, G. (1994). "Implementing Lean Construction: Reducing Inflow Variation." Proc. 2nd Annual Conference of the International Group for Lean Construction (IGLC-2), Santiago, Chile.

Kemmer, S.L., Heineck, L.F.M., and Alves, T.C.L. (2008). "Using the line-of-balance for production system design." Proc. 16th Annual Conference of the International Group for Lean Construction. Manchester. pp.299-308.

LCI (2021). Lean Construction Institute. https://www.leanconstruction.org/.

Mulligan, D.E., and Knutson, K. (2004). Construction and Culture: A Built Environment. Champaign, IL. 2nd Ed.

Olivieri, H., Seppänen, O., Alves, T., Scala, N., Liu, M., and Granja, A.D. (2019). "A survey comparing Critical Path Method, Last Planner System, and Location-Based techniques." J. Constr. Eng. and Manage., ASCE. 145(12): 04019077.

Pestana, A.C.V.M.F., Alves, T. C.L., and Barbosa, A. (2012). "Application of Lean Construction Concepts to Manage the Submittal Process in AEC Projects." Journal of Management in Engineering, ASCE, 30(4): 05014006.

Sweet, J., Schneier, M.M., and Wentz, B. (2015). Construction Law for Design Professionals, Construction Managers, and Contractors. Cengage Learning: Stamford, CT.

Viana, D. D. , Formoso, C. T., and Isatto, E. L. (2011). "Modelling the Network of Commitments in the Last Planner System" Proc. 19th Annual Conference of the International Group for Lean Construction (IGLC). Lima, Peru.

Willis, D. and Alves, T. C. L. (2019). "Contracting for Collaboration in Construction." Proc. 27th Annual C of the International Group for Lean Construction (IGLC). Dublin, Ireland. pp 809-818.

Willis, C, and Friedman, D. (1998). Building the Empire State Building. New York: W.W. Norton \& Company. 